\title{
Commercial Opportunities and Market Demand for Nanotechnologies in Agribusiness Sector
}

\author{
Vincent Sabourin', Alpha Ayande ${ }^{2}$
}

\begin{abstract}
Agribusiness is projected to be a $\$ 2.9$ trillion USD industry in global investment by 2030 (World Bank 20I3). Nanotechnology is poised to impact dramatically on all sectors of agribusiness industry in the next 10 years. Nanotechnology could be used to enhance the possibilities of developing conventional and stranded agribusiness resources. Nanotechnology can make the industry considerably greener and competitive, with its current growth rate of $25 \%$ (US\$ I.08billion) annually. The opportunity for application of nanotechnology in agricul-ture is prodigious. Nanotechnology, focusing on special properties of materials emerging from nanometric size has the potential to revolutionize the agricultural and food sectors, biomedicine, environmental engineering, safety and security, water resources, energy conversion, and numerous other areas. It is well recognized that adoption of new technology is crucial in accu-mulation of global wealth and market value which now stand at US\$ 1.09 trillion in estimated value. Nanotechnology has emerged as a technological advancement that could develop and transform the entire agri-food sector, with the potential to increase agricultural productivity, food security and economic growth for industries by atleast 30\% (Aver. US $\$ 0.9$ trillion). This review set out to address the implications of nanotechnology for the agri-food industry by examining the potential benefits, risks and opportunities.
\end{abstract}

Keywords: agribusiness; nanotechnology; agri-food sector; competitive analysis; market growth

1,2 Consortium Strategy \& Innovation, School of Management of University of Quebec in Montreal. UQAM, ESG School of Management, 315 east St-Catherine Montreal Qc. Canada H3C 4P2. E-mail: 'sabourin.vincent@uqam.ca (corresponding author)

ISSN: 07 I8-2724. (http://www.jotmi.org)

Journal of Technology Management \& Innovation @ Universidad Alberto Hurtado, Facultad de Economía y Negocios. 


\section{Introduction}

Nanotechnology, as a new enabling technology, has the potential to revolutionize agriculture and food systems in the world (European Commission, 20I3). Agricultural and food systems security, disease treatment delivery systems, new tools for molecular and cellular biology, new materials for pathogen detection and protection of the environment are examples of the important links of nanotechnology to the science and engineering of agriculture and food systems (Dlamini et al., 2014; Das et al., 2013; De Azeredo et al., 2013). Agriculture has long dealt with improving the efficiency of crop production, food processing, food safety and environmental consequences of food production, storage and distribution (Banterle et al., 2014; Sekhon 2014). Wilson et al., (2014) argue that nanotechnology is a part of our nation's future. Clearly, this research has an extremely high potential to benefit society through applications in agriculture and food systems. Agriculture is the backbone of most developing countries, with more than $60 \%$ of the population reliant on it for their livelihood (European Commission, 2013; European Food Society Association, 20I4).As well as developing improved systems for monitoring environmental conditions and delivering nutrients or pesticides as appropriate, nanotechnology can improve our understanding of the biology of different crops and thus potentially enhance yields or nutritional values (De Azeredo et al., 2013; Okechukwu, 2014; Wilson et al., 2014; Khodos, 20I4) In addition, Lopez-Salazar et al., (2014) have argued that nanotechnology can offer routes to added value crops or environmental remediation. Globally, many countries have identified the potential of nanotechnology in the agribusiness sector and are investing a significant amount in it (Banterle et al., 2014; Hirsch et al., 2014). Equal importance has been given to the societal issues associated with nanotechnology and to improve agribusiness awareness (De Azeredo et al., 2013). Advanced agribusiness sector has been in production for nearly 30 years (Khodos, 2014). Jalowiecki et al., (2014) have inferred that demand for advanced agricultural products is increasing year on year due to its value addition abilities to its target end users. Apart from this, many new applications have emerged due to commercialization of the manufacturing techniques of agribusiness sector (Kafi and Ghomi, 20I4). Agribusiness sector has huge potential in the future, as it would create a range of applications, namely in industries such as food processing sector, animal husbandry, plant enculturement among others (EFSA, 20I I; Kuan and Ye-Found, 2012; Duran and Marcato, 2013). Thus, an understanding of the nanotechnologies in agribusiness markets and industry would provide intelligence on the entire market segmentation and this would thus, help the stakeholders to make strategic as well as detail oriented decisions.

\section{Objectives of the article}

(i) To study the new possibilities of Nanotechnology in agribusiness sector

(ii) To study the growth and market trends of nanotechnologies in agribusiness sector

(iii) To assess the adoption strategies of Nanotechnology in agribusiness sector

(iv) To identify market segmentation of Nanotechnologies in agribusiness sector

(v) To conduct an evaluation of competitive strategies of Nanotechnology in agribusiness sector

\section{New possibilities of nanotechnology in agribusiness sector}

The increase in human population and demand for habitat, utilizes agriculture land and water resources leading to depletion of key soil nutrients (Bucheli, Knauer and Gogos, 20I3). A report by Duracio et al., (2013) highlighted that a large proportion of those living in developing countries are facing daily food shortages while in the developed world there is a food surplus. European Commission (2013) had earlier reported that for developing countries, the drive is to develop drought and pest resistant crops, which also maximize yield. In developed countries, the agro-food industry is driven by consumer demand for fresher and healthier foodstuffs (European Food Safety Authority, 20I2). Worrying trends in population growth indicate that the food production in near future will not match the ever increasing world population (Dlamini et al., 20l4). In this regard, Banterle et al., (2014) infer that is through innovative agriculture that the world can envisage a self-sustainable agribusiness sector. With limited land and water resources, demand-output ratio in agriculture can be met only by increasing productivity through the effective use of modern technology. Nanotechnology, focusing on special properties of materials emerging from nanometric size has the potential to revolutionize the agricultural and food sectors, biomedicine, environmental engineering, safety and security, water resources, energy conversion, and numerous other areas (Hirsch et al., 20 I4; Dlamini et al., 20I4). In fact several products enabled by nanotechnology are already in the market, such as antibacterial dressings, transparent sunscreen lotions, stain-resistant fabrics, scratch free paints for cars, and self-cleaning windows (Sastry, Aushul and Rao, 20I3). Wilson et al., (2014) have predicted that nanotechnology will transform the entire food industry, changing the way food is produced, processed, packaged, transported, and consumed. An estimate by market research and industry analysis shows that, the market for the nanotechnology was 7.6 billion US\$ in 2008 and was expected to be US\$I trillion in 2030 (Sadano and Vernaeau, 2014). The application of nano-technology in disease control, slow release of

ISSN: 07 I8-2724. (http://www.jotmi.org)

Journal of Technology Management \& Innovation @ Universidad Alberto Hurtado, Facultad de Economía y Negocios. 
pesticides and developing diagnostic tools, and development of functional food systems, to produce interactive, edible nano wrappers to keep the pathogens away, targeted release of chemicals, packaging, extensive nano surveillance, interactive agrochemicals as herbicides and pesticides (Lopez-Salazar et al., 20I4; Brzozowska, 20I4). In terms of emerging trends in global agribusiness sector, Aquaculture is the world's fast growing area of animal production, and it is projected to be one of the first industries to integrate and commercialize nanotechnology products (Duran and Marcato, 2013). Potential applications include nanodelivery of veterinary products in fish food, antibacterial surfaces in the aquaculture system, and nanosensors for detecting pathogens in the water. Although potentially beneficial, there are existing knowledge gaps regarding the impacts of nanoparticles on aquatic organisms (Sekhon, 2014). In plant-based agriculture, emerging applications include nanoformulated agrochemicals (e.g. fertilisers, pesticides, biocides and veterinary medicines) for improved efficiency, reduced use of farm chemicals, new toxin formulations for pest management, and better control of applications (e.g. slow release of pesticides). For example, nanosensors can be used for the detection of pathogens, pesticides and other chemicals. Nanosensors have been applied in pesticide residue detection such as organophosphate in fruit, plants and water (Duran and Marcato, 2013). Khot et al., (2012) have argued that nanosensors offer high sensitivity, low detection limits, super selectivity, fast responses, and small sizes.

\section{Trends of nanotechnology in agribusiness sector}

Agribusiness is projected to be a $\$ 2.9$ trillion USD industry in global investment by 2030 (World Bank 2013). It is therefore understandable that agricultural development in different economies is back on the global development and investment agenda. With investments from sources around the globe, agribusiness started booming in the 2000s. In addition, soaring grain prices and global food inflation spurred investor interest in farming (Vink, 20l0). Many farming projects, linked to the value chain through agri-food processing, food retail establishments and service networks, increasingly do business on the continent, due in part to growing private sector interest (World Bank, 2013). World agriculture attracted more than $\$ 1.8$ trillion in private equity investment in the first half of 2013 , compared with $\$ 0.8$ trillion for the whole of 2012 (Rema and Martinez, 2013). This trend is also recognized and welcomed in the world of government and economic politics. In September 2009, the $\mathrm{G} 20$ recognized agricultural development as a central activity for emerging economies development, echoing the calls of the World Development Report (World Bank, 2 I03). The emerging consensus among development institutions and agencies and strategic investors, referred to in the above paragraphs, has been appreciated as a primary set of forces driving the restructuring of agricultural development in the world economics (Ortega, 20I3; Scoones et al., 20l4). The universally accepted Millennium Declaration, which emphasizes agriculture's prominent role in all eight of the MDGs, together with the declarations by world leaders on the future role of agriculture, clearly situate agriculture's roles and contributions within the broader economicpolitical context of both global and local realities impacting on individual economies (De Janvry, 2009; World Bank, 2013). By 2050, the major growth in demand for food and products is expected to come from the markets of North America, Western Europe and China, and these trends will drive commercial food business systems (Scoones et al., 2014). Demand will be influenced by population growth, per capita income trends, lifestyle aspirations and related consumer preferences. Consumer demand in these regions has become and will continue to be more exacting, fragmented and geared to convenience, food safety and quality (Bairwa et al., 20I4). While these consumers will also seek attributes of fun, surprise and taste sensations in their food experiences they will also be sensitive to environmental, ethical and social considerations (Hughes 2007; Vermeulen et al.2008). According to Khodos (2014), these trends are expected to have profound effects on the sourcing of food products, and will link farm production, processing, wholesaling and retailing. In support of this view, Raynolds et al., (20I4) assert that agri-food value chain will increasingly be subjected to consumer preferences, considerations and values originating in these markets, and the related food safety, environmental and ethical valuations, certifications requirements, traceability and monitoring systems. Another trend that has been witnessed in the agribusiness sector is the changing investment patterns. The restructuring of the agri-food business system is also expected to change the nature of agribusiness investments (Alishahi et al., 2014; Brenes et al., 20l4). For instance, Raynolds et al., (2014) have argued that in order to consolidate value chain actions and allow for scale economics, investments will need to focus on wholesale market infrastructure. The singular purpose of providing farm producers with access to the next level in the value chain will thus shift the emphasis to the development of infrastructure and support systems to facilitate the functioning of all levels of operation in the total agri-value chain (Rhim, Park and Ha, 20I3; Khodos, 20I4). The new drivers of business opportunities in the food system will be investments that focus on agribusiness mentoring, coaching and extension for producers participating in the value chain, and on processing, retail functions, and their mechanisms for support and food safety (Swinnen 20 I0; Reardon et al.2009; McKinsey 201I; World Bank 2013). A report by European Commission (2013) showed that smart field sensing systems are increasingly becoming important applications for the real time monitoring of crop growth and field conditions 
including nutritional status, light, temperature, moisture level, soil fertility, insects, weeds and plant diseases to maximize yields for sustainability in changing climatic conditions. Chen and Yada, (20II) has reported that networks of wireless nanosensors placed across cultivated fields provide detailed information on crop and soil conditions, enabling the best agronomic decisions to be made while minimizing resource inputs. This includes information on the optimal times for planting and harvesting crops, as well as the time and level of water, fertilisers, pesticides, and other treatments that are required to be administered given precise plant physiology, pathology, and environmental conditions (Chen and Yada, 2011). Wireless nanosensors have already been used in certain parts of the U.S. and Australia (Duran and Marcato, 2013). For instance, a Californian vineyard, Pickberry, in Sonoma County has installed $\mathrm{Wi}-\mathrm{Fi}$ systems with the aid of the information technology company, Accenture. The cost of installing this system is rationalized by the fact that it facilitates the best grapes to be grown which in turn produces better-quality wines, which command a premium price (Ditta, 20I2).

\section{The market size of nanotechnology in agribusiness sector}

Global economic reports estimated that the global agribusiness market in 2010 ranged from about US\$20.7 billion to US\$ 0.98 trillion. By 2020 , the market worth is estimated to be more than US\$ 3.4 trillion (BCC, 20I I; Hooley, 20I2).This underscores the value of raising awareness of nanotechnology in agribusiness market, equipping the sector with the skill sets and technical know-how to handle the special technologies and adhere to the Environment, Health and Safety regulations (Bayer, 20I0). In the agri-nano, researchers have highlighted need for technological and engineering issues relating to scalability, quality and reliability of adopting advanced agricultural materials in value addition, as well as the need for closer collaborations amongst the government, academic and industry players to bring down the high cost associated with nano-materials in agribusiness sector. This collaboration will certainly lead to expansion in the projected growth and size of agribusiness market to USD 160 billion by 2020 (see fig I.4.I below.

From the findings of Bukucs et al., (20I4), nanotechnology applications in agriculture has been described as the new industrial revolution and both developed and developing countries are investing in this technology to secure a market share. At present the USA leads with a 4 year, 3.7 billion USD investments through its National Nanotechnology Initiative (NNI) (Schiefer and Hortmann, 2014; Banterle et al., 2014). The USA is followed by Japan and the European Union, which have both committed substantial funds (USD 750 million and USD I.2 billion, including individual country contributions, respectively per year) (Sodano and Vernaeau, 2014). Yusuf (2014) notes that the level of funding in

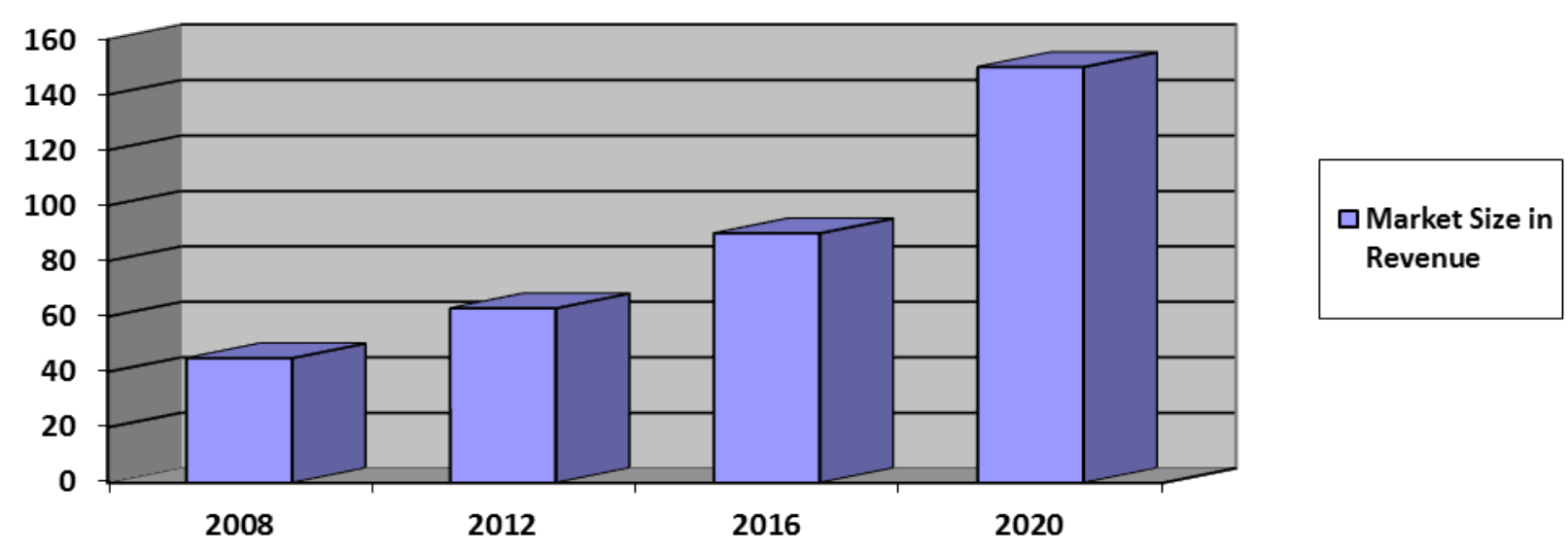

Fig I.4.I The Projected growth and future size of Agribusiness Sector Sourced from BCC Research (2014)

ISSN: 07 I8-2724. (http://www.jotmi.org) 
developing countries may be comparatively lower, however this has not lessened the impact of some countries on the global stage. A recent study from the Helmuth Kaiser Consultancy predicts that the nano-food market will surge from 2.6 billion USD to 20.4 billion USD by 2018 (Brenes et al., 2014). More than 400 companies around the world today are active in nanotechnology research and development (R\&D) and this number is expected to increase to more than 1000 within the next 10 years. In terms of numbers, the USA leads, followed by Japan, China, and the EU. An estimate by the Business Communications Company, a technical market research and industry analysis company shows that, the market for the nanotechnology was 7.6 billion USD in 2003 and is expected to be I trillion USD in 2020 (BCC, 2014). However, Wilson et al., (20l4) argues that the full potential of nanotechnology in the agricultural and food industry has still not been realized. Nanotechnology will leave no field untouched by its ground breaking scientific innovations (Dlamini et al., 20I4). The agriculture and food industry is no exception. Lopez-Salazar et al., (2014) reported that nanotechnology has provided new solutions to problems in animals, plants, plant products and post-harvest technology in enhancing the quality of agricultural products, with a commercial focus. It has a significant effect in the global agribusiness industry - development of new functional materials, product development, and design of methods and instrumentation for food safety and bio-security (LopezSalazar et al., 20l4). This is estimated to grow by $12.5 \%$ for the next 5 years to USDI.9 trillion (Hirsch et al., 20I4).

\section{Market segmentation of nanotechnology in agribusiness sector}

The global agribusiness market sector is segmented majorly by type of application. These applications include:

\section{Nanomaterials in agricultural production segment}

During primary production nano-formulated agro-chemicals are employed to increase the efficacy of the agro-chemicals compared to conventional formulations (De Azeredo et al., 2013; Das et al., 20I3). For example, nano-encapsulated and solid lipid nanoparticles have been explored for the delivery of agrochemicals (Danisch, 2013). The application of novel nanotechnology techniques in agriculture has recently been reviewed by a number of authors (Gogos et al., 2012: Narayanan et al., 2012: Kushwaha et al., 2012: Shamim, 20I I: Mahalik et al., 2010) and can be divided into three main categories; pesticides, plant growth promoters and animal feed additives. Most search results in this category deal with organic nanomaterials, followed by titanium dioxide, silver, silica, and alumina (Shamim, 20I I: Mahalik et al., 20I0). With relation to application, nanotechnology as an emerging field will find agriculture to be deficient market that requires support in terms of research and development (Cota-Arriola et al., 2013; De Azeredo et al., 2013). This direct entry offers a wide market with unending needs that cannot be met.

\section{Nanomaterials in food processing/additives segment}

This segment offers that nanotechnologies are applied in food production machinery and in food additives (CotaArriola et al., 2013). While direct food contact is evident, this application of nanotechnology is expected to have very low additional safety concerns, because migration or carryover to food should be excluded and exposure is therefore expected to be negligible (Plascencia-Jatomea, 2013; CotaArriola et al.,2013).An exception may be cooking equipment, crockery and other kitchenware that may have been treated with nanomaterials to provide it with antibacterial properties (Chen et al., 2010) as in that case the particles are on the surface to exert their microbial activity. Of more importance are food additives which are substances added to food to improve the stability of foods during processing and storage, to improve certain product characteristics, or to increase the potency and bioavailability of nutrients in the food product (Ali et al., 2014; Jalowiecki et al., 2014; Khodos et al., 2014).

\section{Nanomaterials in food contact materials segment}

In this segment, incorporation of nanomaterials or nanotechnological devices in packaging materials or storage containers in order to lengthen the storage time while keeping the products fresh are considered the most important type of nanotechnology application in the food area for the near future (Chaudhry et al., 2010; Cota-Arriola et al., 20I3; Khodos, 20I4). Silvestre and Cimmino (20l3) have inferred that nanocomposites can improve mechanical strength; reduce weight increase heat resistance and improve barrier against oxygen, carbon dioxide, ultraviolet radiation, moisture, and volatiles of food package materials. Main nanoparticles that have been studied for use in food packaging systems as well as their effects and applications were reviewed recently (Vink, (2010; Papaspyrides, 2010: Silvestre et al., 2013).

\section{Adoption strategies of nanotechnology in agribusiness markets}

Ranjan et al., (2014) note that a strategy of adoption consists generally in implanting terminals or installations so as to return the adoption of the new little expensive technology for the buyer. This strategy requires important investments and contains its own risks (Bukucs et al., 2014). However, it facilitates the creation of substitution costs by attaching the buyers to the solution technology which is proposed (Scoones et al., 2014; Markets and Markets, 
2009). As relates to agribusiness markets, Magnuson et al, (2014) argues that there are collaborative alliances among industry, academia and government seeking to raise awareness of Nanotechnology and their impact on everyday growth of agribusiness industry. Wilson et al., (2014) on the other hand note that there is an increased cooperation and coordination among different agribusiness industries, government and academia to advance Nanotechs-driven fields; and drive world funding and investment in areas of agribusiness is critical to maintaining global economic competitiveness and food security. A report by European Commission (2013) and Ali et al., (2014) had indicated that regional innovation clusters in agribusiness markets have also come up and are composed of large companies and SMEs, start-up companies, public and private research \& development centers, universities, specialized suppliers, investors, and regional \& government agencies within a geographic region. They work together in a partnership to follow a common nanotechnology in agribusiness markets is regional development strategy, devised to create synergies in a specific Nanotechs application area (Ortega, 20I3). In the fast-moving agribusiness industry where market competition is very high, continuous development is crucial for the survival of a company (Khodos, 2014). Price discrimination in agribusiness markets is a common behavior where companies charge different prices to different customers as argued by Raynolds et al., (2014). For instance Alishahi et al., (2014) notes that agribusiness companies located within a common region tend to charge varying prices to buyers located in different locales. On this note, Yusuf (2014) also argues those agribusiness based manufacturers are able to skim the market by product innovation, design and development. Companies in agribusiness markets must continually improve the features, benefits, and performance of their products because of continuous advances in technology, competition, and the changing preferences and needs of customers (Kafi and Ghomi, 20l4).

\section{Competitive analysis of nanotechnology in agribusiness sector}

According to Dlamini et al.,(20I4) agribusiness sector has the potential to attract application of nanotechnology as well as herbal medicine industry, both in terms of availability of raw materials, human resources, added value and economic impact of application of nanotechnology. However, Sekhon (2014) notes that the readiness of food industry will be an internal constraint, because the application of nanotechnology will slightly affect many existing products which had long been accepted by consumers. The appearance of new products in the market requires a specific strategy that is not necessarily easy (Brenes et al., 20l4). Although the market in the food industry is very large, however in relation to the application of nanotechnology until, now not all food products can apply nanotechnology because food is generally served after passing through the cooking process, thus affecting or even damage the quality of the function of nano itself (Chaudhry et al., 20I0; Cota-Arriola et al., 2013; Khodos, 2014). On the other hand, although fertilizer industry of the agribusiness sector has potential natural resources and the level of easiness in implementation, its readiness, market scale, scope, availability of research facilities and human resources still remain inadequate (Khodos, 20I4). This according to Ali et al., (2014) is also exacerbated by the dependence on the global dynamics, where the price of raw materials and import of energy is still volatile. Different government support to the fertilizer industry (in the presence of fertilizer and agricultural subsidies) can raise the potential for competitiveness, although until now the impact of the application of nanotechnology in the fertilizer industry is still not widely reported (Yusuf, 2014). Packaging and pesticides industries have the lowest level of competitiveness because almost all criteria (aspects of technology, raw materials, the readiness of human resources, infrastructure and economic impact and influence of global dynamics, etc.) have relatively no significant value in sustaining the competitiveness of the whole sector. Hirsch et al., (2014) report that competitive analysis has highlighted very important process that key players in agribusiness sectors have adopted to action their targets. Specifically, individual countries have established different learning centres to foster quality, thus creating an enabling environment for competition and strategic positioning (Wilson et al., 20l4). There are learning plot activities with target groups to explore technological options and to act as "entry points" for learning communities; establishment of "learning \& information centres" to capture and explain the experiences of learning groups as well as promotion of farmer-to-farmer training and training of trainers (Rhim et al., 2013; Hirsc et al., 2014). These activities are all geared towards creating stronger attraction into the sector by players with massive capital to invest. In this regard, Brzozowska (2014) asserts that competitive sustainability has been nurtured from diverse position of strengthening of input supply chains. This has seen an improvement in transportation, storage, and distribution; business training for suppliers; involvement of dealers in learning and information centres; formation of input associations, etc. While this may be considered as a weak approach to attain competitive position, experts argue that this model is highly reliable as it will ensure that chain processes are closely interlinked for service delivery, product availability (Kushwaha and Malik, 20I2; Kuan and Malik,20I2.According ding to Bairwa, Kushwaha, Meena, Lakra, and Kumar (2014) have contended that different players particularly those from European markets have embarked on the process of strengthening their value chains. This has taken shape in the processing, storage, transportation and marketing of targeted products to key consumers as well as to strategic 
market segments (Bairwa et al., 20l4). Encouraging buyerseller contracts, codes of conduct and industry standard business practices; Hygiene, packaging and labeling practices; strengthening commercial producer associations, are some of the latest competitive processes that have been initiated by the agribusiness sector.

While not forgetting the need to maintain strong financial base, players in food and agribusiness industry have developed models geared towards attracting financial institution into the sector. This has been realized through facilitation of access to credit for farmers and other entrepreneurs involved in the agribusiness cluster through stimulation of savings, guarantee or inventory credit schemes as well as interlinked contracts with buyers.

Competitive pressure has also lead to the strengthening of business development services among key agribusiness players and stakeholders as argued by Schiefer and Hartmann (20I3). This has been witnessed through capacity building in technical issues (e.g. analysis of commodity value chains, inventory credit systems, market analysis, business planning, etc) (Khodos, 20I4). Proper management and decision making frameworks are also vital tools that foster competitive positions in different markets. In this regard, agribusiness players have developed Managerial issue platforms such as, facilitation and leadership skills, networking and lobbying with the sole intent of maintaining their own competitive position as an industry (Khodos, 20 I4; Jalowiecki, 20I4; Okechukwu, 20I4).

\section{Future outlook nanotechnoloy in agribusiness sector}

The dynamic nature of the agribusiness sector provides significant future business challenges and opportunities for future watch. The expected growing demand for food by itself presents potential sales and revenue growth. In addition, the expected future development of the expanding bio-economy with biological based raw materials being used in the energy, industrial and health/pharmaceutical industries adds further potential (Mukhophadhyay, 2014; Brenes et al., 20।4; Ranjan et al., 20I4). According to Hirsch et al., (20I4) the integration of the agricultural sector into the broader overall global industrial economy creates opportunities for new innovative product and service offerings as well as new value chains and markets to deliver those new products and services (Raynolds, et al., 2014). It adds further complexity to an already complex value chain. But according to Dlamini et al., (20I4), that future also is highly uncertain. Many of the management implications of the challenges of strategic uncertainty, innovation and structural change have been identified earlier; however, they can further be highlighted (Arest et al., 2013). Strategic uncertainty requires managers to develop additional capacities to monitor the business climate in which they operate, to anticipate as best one can the impact of the highly improbable, and to regularly reassess the firm's strategic positioning to capture unexpected opportunities and mitigate potential catastrophic losses (Plascencia-Jatomea, 2013; Ranjan et al., 20I4; Ali et al., 20I4). This may require a more flexible rather than focused strategy and a real options mentality embracing more experimentation rather than making "fullblown" or "big bet" commitments (Sastry et al., 2013; Rhim et al., 2013). As to innovations, searching out potentially disruptive technologies or innovations and assessing the risk and rewards of being a first mover vs. fast follower in the commercialization of those technologies or innovations will be critical to capture market potential or defend against new entrants (Brenes et al., 20l4). Systematic and frequent stage-gate processes to evaluate the success potential of innovations as they move from a new idea or invention to commercialization will reduce the risk and enhance the probability of success from innovation (Magnuson et al., 20I I; Sodan and Vernaeau, 20I4). Ali et al., (20I4) note that criteria such as potential return, market un-certainty, technical/regulatory uncertainty, time to market, access to capabilities, and costs al-ready incurred should be included in the selection methods used by companies. On the same note Kafi and Ghomi (20I4) argue that food and agribusiness companies should also rely on several selection methods and on an assessment of the projects by crossfunctional teams as well. Finally, systematically documenting the knowledge created in the innovation process will increase the value created irrespective of whether the product/service offering is a commercial success - learning from and communication on an un-successful innovation or venture has the potential to improve the chances of success in future innovations/ventures (Khodos, 2014; Jalowiecki et al., 20I4; Yusuf, 20I4). Finally, the significant structural changes in the agribusiness sector suggest that managers need to be increasingly vigilant in assessing the competition they will face as well as the opportunities they may have in shaping the restructuring of their industry (Alishahi et al., 2014). The evolution of new value chain structures and industry convergence will require additional leadership and management skills along with new relationships and linkages outside of what have been historical industry boundaries (Sekhon, 20I4). The information, knowledge base and skill set for analyzing and understanding these issues, and making the critical strategic decisions to be successful in an increasingly turbulent business climate, requires integration of concepts from economies, management, finance, decision sciences, organizational behaviour, and strategy. Our goal here has been to make a modest contribution to that knowledge base with a focus on strategic uncertainty, innovation and structural change in the agribusiness sector. 


\section{Conclusion}

Thinking strategically will become increasingly important for successful agribusinesses of the future with respect to nanotechnology application (Brenes, Montoya \& Ciravegna, 2014). The strategic thinking process leverages an understanding of the strengths and weaknesses of the business - leading to an identification of the core competencies and capabilities - to respond to the opportunities and threats provided by the external environment (Bukucs et al., 2014). Only by understanding internal capacities and the external environment can the successful manager analyze the strategic positioning options available to the business. Choosing a strategic position of operational excellence/ low-cost leader, product/process innovation or customer intimacy based on this analysis provides the manager with a fundamental direction for the business that can shape its ability to create value for its customers. And that is what the successful agribusiness of tomorrow will be a business that understands customers and determines how to create value for those customers through products and services that creates a long-term sustainable competitive advantage through an operational excellence/low cost, product/process innovation or customer intimacy strategy.

\section{About Authors}

The authors are professor and director and post-doctoral student at the Consortium Strategy \& Innovation of the School of Management of University of Quebec in Montreal. They wish to thank Festus Memba for supporting the development of this article in a professional and diligent manner. 


\section{Appendix}

Fig I.0: model for the Plan of action of Nanotechnology in Agribusiness Market

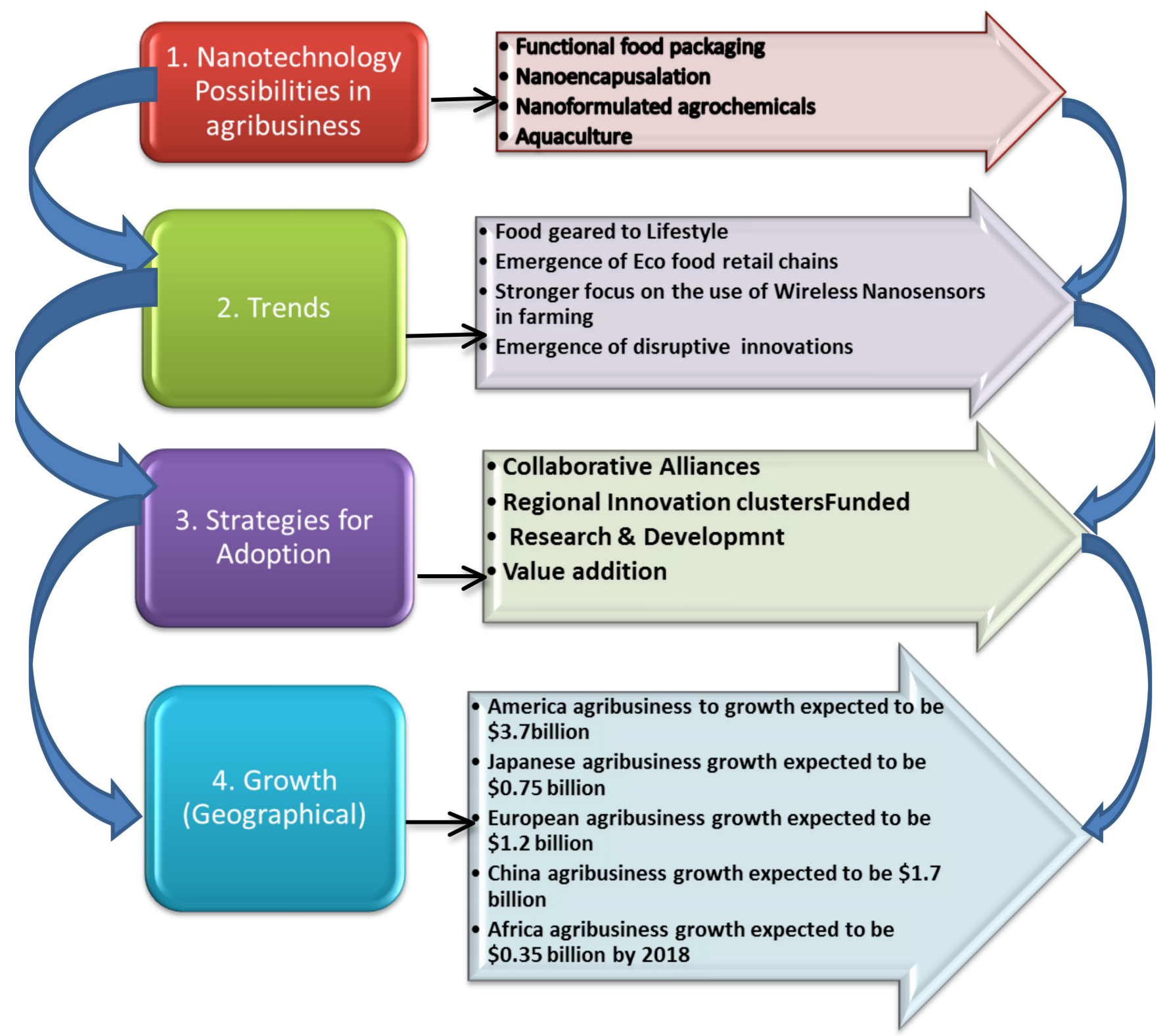

Source: Business Communication Company (2014) 


\section{References}

ALI, M. A., Rehman, I., Iqbal, A., ud Din, S., Rao, A. Q., Latif, A., \& Husnain, T. (20|4). Nanotechnology: A new frontier in Agriculture.Advancements in Life Sciences, I (3), I 29-I 38.

ALISHAHI, A., Proulx, J., \& Aider, M. (20I4). Chitosan as Biobased Nanocomposite in Seafood Industry and Aquaculture. Seafood Science: Advances in Chemistry, Technology and Applications, 2I I. DOI: I0.120I/b |7402-12

AMNA,T and Hassan, M.,S., (20I3). Inactivation of Foodborne Pathogens by $\mathrm{NiO} / \mathrm{TiO} 2$ Composite Nanofibers: A Novel Biomaterial System. Food and Bioprocess Technology, 6, 988996. DOI: 10.1007/s I I947-0I I-074I-I

ARESTA, A, Calvano C., D., Trapani, A., Cellamare, S., Zambonin, C., G., and De Giglio, E., (20/3). Development and analytical characterization of vitamin(s)-loaded chitosan nanoparticles for potential food packaging applications. Journal of Nanoparticle Research, I5:I592-1597. DOI: |0.1007/s| |05|-0|3-1592-7

BAIRWA, S. L., Kalia, A., Meena, L. K., Lakra, K., \& Kushwaha, S. (20I4). Agribusiness Management Education: A Review on Employment Opportunities. International Journal of Scientific and Research Publications (IJSRP), 4(2), I-4.

BAIRWA, S. L., Kushwaha, S., Meena, L. K., Lakra, K. and Kumar P. (2014) Agribusiness Potential of North Eastern States: A SWOT Analysis. Edited by Singh et al., 2014 "Agribusiness Potentials in India: experience from hill states". EBH Publishers (India) Guwahati New Delhi. PP 544-556

BAIRWA, S. L., Kushwaha, S., Meena, L. K., Lakra, K. and Kumar P. (20/4) Agribusiness Potential of North Eastern States: A SWOT Analysis. Edited by Singh et al., 2014 "Agribusiness Potentials in India: experience from hill states". EBH Publishers (India) Guwahati New Delhi. PP 544-556

BAKUCS, Z., Fałkowski, J., \& Fertő, I. (20।4). Does Market Structure Influence Price Transmission in the Agro-food Sector? A Meta-analysis Perspective. Journal of Agricultural Economics, 65(I), I-25. DOI: I0. I I I //477-9552. 12042

BANTERLE, A., Cavaliere, A., Carraresi, L., \& Stranieri, S. (20I4). Food SMEs Face Increasing Competition in the EU Market: Marketing Management Capability Is a Tool for Becoming a Price Maker. Agribusiness, 30(2), I|3-131. DOI: 10.1002/agr.21354
BRENES, E. R., Montoya, D., \& Ciravegna, L. (2014). Differentiation strategies in emerging markets: The case of Latin American agribusinesses. Journal of Business Research, 67(5), 847-855. doi:10.1016/j.jbusres.2013.07.003

BRZOZOWSKA, A. (20I4). Management, Budgeting And Evaluation Of The Rural Development Programme In Agribusiness Logistic Systems In Poland.

BUCHELI, T., D., Knauer, K, Gogos, A, (2013). Overview of agricultural applications of nanotechnology; Nanotechnology for the agricultural sector: from research to the field; Workshop organized by JRC IPTS Agrilife Unit, 21 - 22 November 2013, Seville, ES.

CHANDRASEKARAN N, (20/3). Distinctive effects of nano-sized permethrin in the environment. Environmental Science and Pollution Research, 20, 2593-2602. DOI: |0.1007/s I|356-0|2-I|6|-0

CHEN L, Zheng L, Lv Y, Liu H, Wang G, Ren N, Liu D, Wang $\mathrm{J}$ and Boughton RI, (2010). Chemical assembly of silver nanoparticles on stainless steel for antimicrobial applications. Surface Coatings Technol., 204, 387 I.

CHIN CP, Wu HS and Wang SS, (201 I). New Approach to Pesticide Delivery Using Nanosuspensions: Research and Applications. Industrial \& Engineering Chemistry Research, 50, 7636-7643. doi:I0.I016/j.surfcoat.2010.05.003

CHOUDHURY SR, Nair KK, Kumar R, Gogoi R, Srivastava C, Gopal., M, Subhramanyam, B., S, Devakumar C and Goswami A, (20I0). Nanosulfur: A potent fungicide against food pathogen, Aspergillus niger. AIP Conference Proceedings, |276, I54-|57. DOI: 10.102 |/ie2001007

COTA-ARRIOLA O, Onofre Cortez-Rocha M, BurgosHernández A, Marina Ezquerra-Brauer J and PlascenciaJatomea M, (2013). Controlled release matrices and micro/ nanoparticles of chitosan with antimicrobial potential: Development of new strategies for microbial control in agriculture. Journal of the Science of Food and Agriculture, 93, I525-I536. DOI: 10.1002/jsfa.6060

DANISCH EPA, (2013). Systemic Absorption of Nanomaterials by Oral Exposure. Report Environmental Project No. I 505, 2013.

DAS SK, Khan MR, Parandhaman T, Laffir F, Guha AK, Sekarana $G$ and Mandal AB, (20I3). Nano-silica fabricated with silver nanoparticles: antifouling adsorbent for efficient dye removal, effective water disinfection and biofouling control. Nanoscale, 5, 5549-5560. DOI: 10.1039/C3NR00856H 
DE AZEREDO MCH, (20I3). Antimicrobial nanostructures in food packaging, Trends in Food Science \& Technology, 30, 56-69. doi:10.1016/j.tifs.2012.11.006

DE STEFANO D, Carnuccio, R., and Maiuri M, C, (20I2). Nanomaterials Toxicity and cell Deatch Modalities. J. Drug Discovery, doi: I0.1 155/2012/167896.

DEBNATH N, Das S and Goswami A, (20II). Novel entomotoxic nanocides for agro-chemical industry. Proceedings of the IEEE Conference on Nanotechnology, PP 53-56. DOI: 10.1 109/NANO.20II.6144360

DLAMINI, B. P., Kirsten, J. F., \& Masuku, M. B. (20I4). Factors Affecting the Competitiveness of the Agribusiness Sector in Swaziland. Journal of Agricultural Studies, 2(I), 6I-72. DOI: http://dx.doi.org//0.5296/jas.v2il.4775

DURACCIO D, Silvestre C, Pezzuto M, Cimmino, S and Marra, A, (2013). Polypropylene and Polyethylene-Based Nanocomposites for Food Packaging Applications. In: Ecosustainable Polymer Nanomaterials for Food Packaging, CRC Press, pp. I43-168. DOI: I0.120I/b /3754-7

DURÁN., N, and Marcato, P., D., (20I3). Nanobiotechnology perspectives. Role of nanotechnology in the food industry: $A$ review. International Journal of Food Science and Technology, 48, I I 27- I |34. DOI: I0. I I I //ijfs. 2027

EFSA Scientific Committee.(20II). Guidance on the risk assessment of the application of Nanoscience and nanotechnologies in the food and feed chain. EFSA Journal 9 (5): 2 । 40.

EUROPEAN COMMISSION (DG SANCO) (2013). Assessment of nanomaterials in food, health and consumer products. Workshop on the Second Regulatory Review on Nanomaterials. D. H. a. Consumers. Brussels.

MAURICI, D., (20II). A genotoxicity testing strategy proposed by the European Food Safety Authority (EFSA) for food and feed risk assessment. Parma, Italy: European Food Safety Authority. doi: 10.1016/j.toxlet.201 I.05.90I

GOGOSA, Knauer K and Buchell T, D, (2012). Nanomaterials in plant protection and fertilization: Current state, foreseen applications, and research priorities. Journal of Agricultural and Food Chemistry, 60, 978I-9792. DOI: 10.102 I/jf302 I54y.

HIRSCH, S., Schiefer, J., Gschwandtner, A., \& Hartmann, M. (20/4). The Determinants of Firm Profitability Differences in EU Food Processing. Journal of Agricultural Economics. DOI: |0.1 I I I/|477-9552.1206 I.
JAŁOWIECKI, P., Woźniakowski, T., \& Ząbkowski, T., (20I4). Some Remarks On Logistics Investments Among Polish Food Processing And Agribusiness Companies. Beata Butryn, Piotr Machura, I22. http://dx.doi.org// 0. I I55/20 I 4/754038.

KAFI, F., \& Ghomi, F., S. (20I4). A Game-Theoretic Model to Analyze Value Creation with Simultaneous Cooperation and Competition of Supply Chain Partners. Mathematical Problems in Engineering, 2014.

KHODOS, D. (2014). Economic Mechanism Of Innovative development of Agricultural Sector. Innovation Management and Company Sustainability, 26, 73.

KOLE C, KOLE P, Manoj Randunu K, Choudhary P, Podila K, Chun Ke P, Rao AM and Marcus RK, (20I3). Nanobiotechnology can boost crop production and quality: first evidence from increased plant biomass, fruit yield and phytomedicine content in bitter melon (Momordica charantia). BMC Biotechnol, I3. doi:I0.I I86/I472-6750-I337.

KUAN, C., Y., and Yee-Fung W, (20 I 2). Nanotech: Propensity in foods and bioactives. Critical Reviews in Food Science and Nutrition, 52, 55-7I. DOI: 10.1080/I0408398.2010.494259

KUSHWAHA, H., B., and Malik, C., P., (20I2). Contributions of Nanotechnology in agriculture and food processing. Phytomorphology: An International Journal of Plant Morphology, 62, 57-67.

LÓPEZ-SALAZAR, A., López-Mateo, C., \& Molina-Sánchez, R. (20I4). What Determines the Technological Capabilities of the Agribusiness Sector in Mexico?. International Business Research, 7(10), p47. DOI: I0.5539/ibr.v7n I0p47.

LU., J., and Bowles., M., (20I3). How Will Nanotechnology Affect Agricultural Supply Chains? International Food and Agribusiness Management Review Volume 16, Issue 2, 2013

MAGNUSON, B., A., Jonaitis, T., S., and Jeffrey, W., (201 I). A Brief Review of the Occurrence, Use, and Safety of Food-Related Nanomaterials. Journal of Food Science. 76 (6):RI26-RI33. DOI: I0.IIII/j.I750-384I.20II.02I70.x

MUKHOPADHYAY, S. S. (2014). Nanotechnology in agriculture: prospects and constraints. Nanotechnology, science and applications, 7, 63. http://dx.doi.org//0.2/47/ NSA.S39409.

NARAYANAN A, Sharma $P$ and Moudgil BM, 2012. Applications of engineered particulate systems in agriculture and food industry. KONA Powder and Particle Journal, 30, 22 I-235. http://dx.doi.org/I0.14356/kona.201302I.

ISSN: 07 I8-2724. (http://www.jotmi.org) 
OKECHUKWU, O., T., (20I4). Critical Factors Influencing the Entrepreneurial Undergraduate's Decision Venturing into Agribusiness in Ebonyi State, (A Case Study of Ebonyi State Universty). Journal of Natural Sciences Research, 4(19), 33-38.

ORTEGA, D. L. (2013). Modernizing Agrifood Chains in China: Implications for Rural Development. American Journal of Agricultural Economics, 95(4), I046-I048. doi: 10.1093/ajae/ aat0II.

PAPASPYRIDES CCD, 2010. Nanotechnology and food contact materials, AIP Conference Proceedings, 1255, 234236.

RAMA, R., \& Martínez, C.(20I3).The changing structure of the global agribusiness sector. Handbook of Industry Studies and Economic Geography, 305. DOI:I 0.4337/978I 782549000.

RANJAN, S., Dasgupta., N., Chakraborty., A., R, Samuel S., M., Ramalingam, C., Shanker, R., Kumar, A., (20I4) Nanoscience and nanotechnologies in food industries: opportunities and research trends. Journal of Nanoparticle Research : 16:24642487. DOI: |0.1007/s | I05 I-0|4-2464-5.

RASHIDI, L, Khosravi-Darani, K., (20II). The Applications of Nanotechnology in Food Industry. Critical Reviews in Food Science and Nutrition : 51:723-730. DOI: 10.1080/10408391003785417

RAYNOLDS, L. T., Long, M. A., \& Murray, D. L. (20I4). Regulating Corporate Responsibility in the American Market: A Comparative Analysis of Voluntary Certifications. Competition \& Change, I8(2), 91-II0. doi: I0.1 I79/102452 94I4Z.00000000050.

REARDON,T., C. Barrett, J. Berdegué and J. Swinnen. (2009). Agrifood Industry Transformation and Small Farmers in Developing Countries. World Development; 37 (II): 17171727. doi:10.1016/j.worlddev.2008.08.023.

RHIM, J.,W, Park, H., M, Ha C.,S.,(20I3). Bio-nanocomposites for food packaging applications. Progress in Polymer Science: 38(10):1629-1652. doi:10.1016/j.progpolymsci.2013.05.008.

SASTRY., R., K,Anshul.,S, Rao., N., H., (2013) Nanotechnology in food processing sector- An assessment of emerging trends, Journal of Food Science and Technology 50:83 I-84I. DOI: I0.1007/s | 3197-0 I2-0873-y.

SCHIEFER, J., \& Hartmann, M. (20I3). Industry, firm, year, and country effects on profitability in EU food processing. Institute for Food and Resource Economics, University of Bonn. Discussion Paper, 2.
SCOONES, I., Smalley, R., Hall, R., \& Tsikata, D. (20I4). Narratives of scarcity: understanding the 'global resource grab'.

SEKHON, B., S., (2014). Nanotechnology in agri-food production: an overview. Nanotechnology, Science and Applications 7: 31-53. http://dx.doi.org//0.2/47/NSA. S39406.

SILVESTRE, C., Cimmino, S. (2013). Ecosustainable Polymer Nanomaterials for Food Packaging, CRC Press, New York, US. DOI: I0.1201/b |3754-2.

SODANO, V., \& Verneau, F. (20I4). Competition Policy and Food Sector in the European Union. Journal of International Food \& Agribusiness Marketing, 26(3), I55- I 72. DOI: 10.108 0/08974438.20I3.833576

SRIVASTAVA, S., Mathur, D. H., \& Kumar, M. (20I4). Competitive Advantage \&Value Chain Analysis Of Small Scale Fruits \& Vegetable Processing Industry. International Journal of Logistics \& Supply Chain Management Perspectives, 2(4), 778-790.

TILMAN D, Balzer C, Hill J, Befort BL., (20II). Global food demand and the sustainable intensification of agriculture, Proceedings of the National Academy of Sciences: 108: 20260-20264. doi: 10.1073/pnas. I I I6437I08

TIMMER, P. (20I0). Lessons from Food Crises Past. Center for Global Development, Washington D.C.

TYLER, L. C. (20I2). "FDA Issues Draft Guidance on Use of Nanotechnology in Food and Food Packaging." Nanotechnology Law \& Business 9: I49-I 55.

VINK, N. (2010). Agribusiness Policy and Strategy in the Future. 2010 Conference of the Agricultural Business Chamber (ABC), Lord Charles Hotel. Somerset West, South Africa.

WILSON, W. W., Shakya, S., \& Dahl, B., (20l4). Dynamic Changes in Spatial Competition for Fertilizer. doi:10.1016/j. agsy.2014.1I.006

WORLD BANK (20I3). Growing Africa: Unlocking the Potential of Agribusiness. AFTFP/AFTAI. World Bank: Washington D.C.

YUSUF, S. A. (20I4). The Analysis of Export Performance of Newly Industrialized Countries (NICs): The Lesson for African Countries. 